\title{
Možnosti zapojenia žiakov do praktickej ochrany prírody v rámci akcie „Pomoc ropuchám pri jarných migráciách" na Železnej studienke v Bratislave (1986-2015)
}

\author{
Blanka Lehotská, Alena Magyarics \\ Envigogika 10 (4) - Reviewed Papers/Recenzované články \\ Publikováno/Published dne 29. 12. 2015
}

DOI: $\underline{10.14712 / 18023061.496}$

\begin{abstract}
Abstrakt
Príspevok prezentuje jednu z možností zapojenia žiakov do praktickej ochrany prírody. Zaoberá sa problematikou ochrany migrujúcich obojživelníkov. Na základe 30-ročných skúseností z ochrany populácie ropuchy bradavičnatej (Bufo bufo) na Železnej studienke v Bratislave špecifikuje možnosti zapojenia žiakov do konkrétnych aktivít. Zároveň zdôrazňuje pozitívny vplyv účasti žiakov na týchto aktivitách na ich vedomostnú úroveň a postoj $k$ ochrane prírody a životného prostredia. Na Slovensku aj v Českej republike je evidovaných množstvo lokalít, na ktorých každoročne dochádza k úhynom zákonom chránených živočíchov. Predkladaný príspevok je určitým návodom a inšpiráciou pre učitelov, ako môžu spolu so žiakmi prispiet́ k zmene tejto situácie.
\end{abstract}

\section{Kl'účové slová}

aktivity pro žáky; ochrana prírody; environmentální výchova; jarní migrace obojživelníků

\begin{abstract}
The paper presents one of the possibilities of the involvement of school children in practical nature conservation. It deals with the conservation issue of migrating amphibians. Based on 30 years of experience in protection of the common toad (Bufo bufo) population nin the Železná studienka locality in Bratislava, it specifies how to involve pupils in particular activities. At the same time it emphasizes the positive impact of school children participation in these activities on their knowledge level and attitude to nature conservation and environment protection. In Slovakia and the Czech Republic the number of sites is recorded where an annual mortality of protected animals is observed. This contribution is a guide and inspiration for teachers to show that pupils can work alongside them tocontribute to changing this situation.
\end{abstract}

\section{Key words}

activities for school children; nature conservation; environmental education; spring migrations of amphibians 


\section{Úvod}

Základom šírenia environmentálnych poznatkov je všeobecná školská výchova, ktorá predstavuje aj proces poznávania hodnôt, rozvoja poznatkov a postojov $\mathrm{k}$ oceňovaniu vzt́ahov človeka a jeho kultúry $\mathrm{k}$ jeho životnému prostrediu. Výchova vedie $\mathrm{k}$ získaniu skúseností, ktoré môže jedinec následne využit pri rozhodovaní sa, či rozvoji foriem správania sa k okolitému životnému prostrediu (Nevřelová, 2008). Environmentálna výchova by mala vytvárat́ optimálny vztáah $\mathrm{k}$ životnému prostrediu, a to vo výchovnom priestore rodiny (základy morálno-etického vztahu k prírode), školy (výchovné a vzdelávacie pôsobenie) a doplňujúceho vzdelávania (kurzy, projekty, mimoškolské programy a pod.) (Kminiak, 1997). Environmentálna výchova má v súčasnosti svoje zastúpenie $v$ pedagogickom procese na základných školách. Učitelia počas školského roka realizujú so žiakmi rôzne aktivity, ktorých ciel'om je nielen u detí rozširovat' a upevňovat́ vedomosti, ale aj podporovat́ praktické skúsenosti s riešením problémov $v$ životnom prostredí, rozvíjat' a upevňovat' hodnotový systém $v$ prospech konania smerom $k$ životnému prostrediu od globálnej úrovne až po konkrétne aktivity zamerané na ochranu prírody na lokálnej úrovni (Novanská, 2014).

V poznávaní prírodných javov a zákonitostí má nezastupitel'né miesto realizácia praktických cvičení, vychádzok či exkurzií, na ktorých majú žiaci možnost́ nielen pasívne prijímat' informácie o životnom prostredí, ale prostredníctvom rôznych činností sa aj aktívne podiel'at' na spoznávaní fungovania ekologických väzieb, faktorov, ktoré môžu tieto väzby narušit', či možnostiach ako negatívnym lúdským vplyvom predchádzat' alebo ich zmiernit'.

Výskum medzi učitel'mi základných škôl na Slovensku (Chrenščová, 2012) priniesol pozitívne výsledky týkajúce sa využívania exkurzií vo vyučovacom procese a pri realizácii environmentálnej výchovy. Využívané sú najmä medzipredmetové exkurzie, v rámci ktorých žiaci poznávajú bežné prírodné, spoločenské a kultúrne prostredie. Aj napriek tomu, že často na učitel'a kladú zvýšené organizačné a časové nároky, učitelia ich považujú za opodstatnenú formu vzdelávania a preto je táto forma výučby na školách pomerne častá.

Ciel'om nášho príspevku bolo poukázat́ na jeden z mnohých príkladov zapojenia žiakov nielen do poznávania ich okolitého životného prostredia, ale aj do praktickej ochrany prírody. V rámci akcie "Pomoc ropuchám pri jarných migráciách", ktorú zabezpečuje Základná organizácia Slovenského zväzu ochrancov prírody a krajiny (ZO SZOPK) Miniopterus v spolupráci so Štátnou ochranou prírody SR - Správou CHKO Malé Karpaty na Železnej studienke v Bratislave, sú žiaci zapájaní do záchrany migrujúcich obojživelníkov už 30 rokov. Obdobných miest, na ktorých každoročne dochádza $\mathrm{k}$ úhynu zákonom chránených živočíchov, sú na Slovensku a v okolitých štátoch stovky, avšak nie vždy je $v$ silách štátnych orgánov (z hladiska personálneho aj finančného) zabezpečit týmto živočíchom adekvátnu ochranu. Preto je z ich strany vždy vítaná spolupráca s rôznymi občianskymi združeniami, či odbornými organizáciami, ktoré prevezmú patronát nad jednotlivými lokalitami.

\section{História a priebeh akcie „Pomoc ropuchám pri jarných migráciách" na Železnej studienke $v$ Bratislave}

V nadväznosti na celoslovenské mapovanie výskytu obojživelníkov, ako aj faktorov ich ohrozenia a stavu ich biotopov, ktoré prebiehalo v polovici 80. rokov minulého storočia nielen na území Československa, ale aj v susedných štátoch, bola k 1. marcu 1986 vyhlásená Ústredným výborom Slovenského zväzu ochrancov prírody a krajiny (ÚV SZOPK) akcia „Pomoc ropuchám pri jarných migráciách" (Lehotská, Lehotský, 2000). Jej ciel'om je zabezpečenie ochrany pre ropuchy bradavičnaté (Bufo bufo) a čiastočne aj skokanov rodu 
Rana, ktoré na cestách počas svojich jarných migrácií masovo hynú pod kolesami automobilov. Tieto druhy patria k zákonom chráneným živočíchom a spoločenská hodnota jedného jedinca je podla Vyhlášky MŽP SR č. 158/2014 Z. z. u druhu Bufo bufo stanovená na $230 €$ ( $v$ prípade Rana temporaria $140 €$ ).

Jednou z lokalít, na ktorých bol pozorovaný pravidelný úhyn obojživelníkov už od 70 . rokov (Kováčik, 1974; Kminiak, Kováčik, 1975) bola Železná studienka. Ide o známu rekreačnú oblast' obyvatel'ov Bratislavy, ktorá sa nachádza v Hornej Mlynskej doline a je súčastou Bratislavského lesoparku v južnej časti CHKO Malé Karpaty. Územím preteká potok Vydrica, ktorý napája vodou 4 rybníky. Rybníky sa v súčasnosti využívajú na rybolov a dva z nich bývajú v letnom období využívané aj na člnkovanie.

Najúčinnejším opatrením ako zabránit úhynu migrujúcich obojživelníkov v oblasti Železnej studienky by samozrejme bola úplná uzávierka cestnej komunikácie $v$ čase migrácie. Kedže túto alternatívu nie je možné zrealizovat', pristúpilo sa ku každoročnému budovaniu záchytných zábran. Samotná akcia „Pomoc ropuchám pri jarných migráciách" na Železnej studienke $v$ Bratislave ( $v$ roku 2015 sa uskutočnil jej 30. ročník) pozostáva z troch nosných etáp: stavba zábran, zber a prenášanie ropúch do rybníkov a odstránenie zábran, pričom do jednotlivých etáp sa rôznym spôsobom majú možnost́ zapojit' aj žiaci základných a stredných škôl. Po týchto etapách nasleduje záverečné vyhodnotenie akcie.

Na stavbu zábran sa v prvých rokoch používala čierna fólia, ktorá však bola pomerne tenká a preto sa často trhala. Postupne sa nahradila červenou elektrikárskou fóliou vysokou 30-35 centimetrov, ktorá je pevnejšia a trvácnejšia. Zábrany sa v súčasnosti stavajú na dvoch čiastkových úsekoch $v$ celkovej dížke cca $650 \mathrm{~m}$ ( $\vee$ minulosti sa $\vee$ niektorých rokoch stavali zábrany na 3 úsekoch s celkovou dížkou až $1140 \mathrm{~m}$ ). Najprv je potrebné pozdíž cesty na okraji lesného porastu motykami vykopat' jarček (obr. 1), do ktorého sa fólia zvisle umiestni a pripevní pomocou drevených zašpicatených kolíkov (obr. 2). Na výrobu kolíkov sa používa popadané drevo z okolitého lesa. Na koncoch zábran sa vybudujú záchytné jamy. Na záver sa zábrany pri zemi prihrnú hlinou, aby ich migrujúce žaby nemohli podliezt́. Takto postavené zábrany slúžia predovšetkým na zachytenie ropúch (obr. 3). Skokany vzhladom na ich odlišnú stavbu tela (najmä dížku zadných končatín) sú schopné zábrany preskočit'. Zároveň sa vedia aj omnoho rýchlejšie presunút z vozovky, nakolko sa pohybujú vel'kými skokmi. Na rozdiel od skokanov, ropuchy neskáču, skôr lezú a pohybujú sa omnoho pomalšie, takže hrozba kolízie s motorovými vozidlami je omnoho väčšia.

Časovo a organizačne najnáročnejšou etapou samotnej akcie je zber (obr. 4) a prenos ropúch (skokany je možné nájstt pri zábranách len ojedinele) spoza zábran, príp. z cesty do rybníkov (obr. 5). Ropuchy sa chytajú priamo do ruky a na ich prenos sa používajú plastové vedrá. $\vee$ rybníku dochádza $v$ priebehu niekolkých dní $\mathrm{k}$ ich páreniu a následnému kladeniu vajíčok (obr. 6). O počte zachránených a usmrtených jedincov sa každoročne vedie evidencia. Zatial' čo v prvých rokoch usmrtené ropuchy tvorili 30-45 \% z celkového počtu zaznamenaných jedincov, postupne sa podarilo znižit ich úmrtnost́ na vozovke na 3-5 \%. K úhynu dochádza najmä na úsekoch, kde nie sú zábrany, nakolko zábrany sa inštalujú len na "najkritickejších" úsekoch, t.j. úsekoch $v$ tesnej blízkosti rybníkov. Celkový počet prenesených, a teda zachránených ropúch na Železnej studienke sa pohybuje $v$ priemere okolo 4000 - 6000 jedincov. Rekordným rokom je rok 1996, kedy bolo prenesených až 13844 ropúch. Počty medziročne kolíšu jednak $z$ dôvodu výkyvov $v$ populácii ropuchy bradavičnatej a $v$ súvislosti $s$ aktuálnymi poveternostnými podmienkami $v$ období migrácie, ale aj z dôvodu rôznej dížky nainštalovaných zábran a rôznej návratnosti údajov. $V$ prvých rokoch sa do akcie zapájalo pomerne málo l'udí, preto sa podarilo získat' a vyhodnotit́ takmer všetky záznamy o prenose. $V$ posledných rokoch sa (aj vd'aka jej 30-ročnému trvaniu a skutočnosti, že je dobre známa medzi občanmi Bratislavy) do akcie iniciatívne zapája 
množstvo rodín s det́mi, ktoré síce prenesú ropuchy cez cestu do rybníkov, ale nenahlásia ich počet, takže celkové počty prenesených žiab sú z tohto dôvodu do istej miery podhodnotené. Preto akcia nesleduje striktne vedecký ciel' (zmena početnosti populácie, či vplyv manažmentových opatrení na populáciu), ale skôr výchovno-vzdelávací ciel' (zvýšenie environmentálneho povedomia u detí, mládeže, aj dospelých) a smeruje k zabezpečeniu ochrany čo najväčšieho počtu migrujúcich jedincov.

Ku koncu migrácie, ked'sa niektoré jedince už začínajú vracat' z rybníka spät do lesa, je potrebné klást́ velký dôraz na to, aby sa už takéto jedince nepremiestňovali spät' do rybníka, čím by museli prekonávat' prechod cez vozovku ešte raz. Ked’ už väčšina ropúch migruje spät z rybníka do lesa je potrebné fólie odstránit'. Toto je ciel'om záverečnej etapy odstránenia zábran. Ak by sme túto etapu zanedbali, zabránili by sme tak dospelým jedincom rozliezt' sa do širokého okolia. Niektoré jedince sa vracajú z rybníka už v čase, kedy ešte iné migrujú do vody. Preto je potrebné dôkladne sledovat' priebeh migrácie a čo najpresnejšie stanovit́ termín odstránenia zábran.

\section{Pôsobenie akcie na ekologické myslenie žiakov a možnosti ich zapojenia}

Z údajov o počte každoročne zachránených žiab vidiet' zretelný prínos akcie "Pomoc ropuchám pri jarných migráciách" na lokalite Železná studienka (Lehotská, Lehotský, 2000). Svoju úlohu zohráva pritom aj osveta. Do jednotlivých etáp akcie sa každoročne zapájajú členovia rôznych záujmových krúžkov, žiaci základných škôl, študenti stredných a vysokých škôl a milovníci prírody z radov širokej verejnosti. Každý návštevník Železnej studienky, ktorému nie je úplne láhostajná naša práca, sa môže priamo na mieste dozvediet́ podrobnejšie informácie o akcii a jej význame. Informácie o dianí v tejto oblasti sa dostávajú aj do masovokomunikačných prostriedkov (tlače, rozhlasu a televízie). Je to jedna z možností pôsobenia na environmentálne povedomie občanov. Pre väčšinu Bratislavčanov je to jediná známa akcia $z$ oblasti praktickej ochrany prírody $s$ možnostou priameho zapojenia sa širokej verejnosti, ktorá sa uskutočňuje na území hlavného mesta SR a ako taká si počas svojho trvania získala množstvo prívržencov.

Praktické zapojenie sa žiakov základných škôl je možné do všetkých troch nosných etáp akcie. Na stavbe zábran (ako fyzicky najnáročnejšej etape, ktorá trvá $1-2$ dni) sa okrem verejnosti podielajú najmä študenti vysokých škôl (predovšetkým z Prírodovedeckej fakulty Univerzity Komenského $v$ Bratislave). Zapájajú sa do nej však aj žiaci základných škôl, ktorí častokrát prichádzajú pomôct́ nielen spolu so svojimi učitel'mi, ale aj s rodičmi. Pre každého $v$ závislosti od jeho veku a zručností sa pri stavbe zábran nájde činnost', ktorou môže pomôct' - výroba drevených kolíkov, kopanie jarčeka, zatíkanie kolíkov do zeme a pripevňovanie fólie, zahrabávanie fólie, nosenie a podávanie kolíkov atd'. Ked' sú zábrany postavené a žaby začnú migrovat', začína sa druhá etapa, do ktorej sa tradične zapájajú najmä žiaci základných škôl. $\vee$ posledných rokoch to boli aj deti z viacerých materských škôl. Prenosy sa organizujú každý deň $v$ dopoludňajších hodinách ( $v$ čase vrcholenia migrácie aj večer, resp. $v$ priebehu celého dňa). Záujem o prenos je zo strany škôl velký a v niektorých rokoch dokonca prevýšil počet dní migrácie. Pri zostavovaní harmonogramu prenosov sa preto snažíme uprednostnit školy, ktorých žiaci sa podielali aj na stavbe zábran a samotný prenos je pre nich určitou formou odmeny. Po skončení migrácie je potrebné zábrany odstránit', aby nebránili ropuchám dostat' sa naspät do lesného prostredia. Nakolko čistenie a zmotávanie zábran je omnoho jednoduchšie ako ich stavba, aj v tejto etape sa otvára priestor pre zapojenie žiakov do tejto aktivity. Každoročne sa do akcie zapája okolo 250- 
400 účastníkov ( $v$ závislosti od dížky trvania migrácie), pričom cca 80 \% z nich tvoria žiaci základných škôl.

\section{Výsledky hodnotenia úrovne poznatkov žiakov o obojživelníkoch na základných a stredných školách v Bratislave}

Pomocou didaktického testu (Danková, 2008) sme zistóvali úroveň vedomostí žiakov o obojživelníkoch, konkrétnejšie o ropuchách $v$ závislosti od toho, či sa žiaci zúčastnili prenosu žiab alebo nie. Test obsahoval 21 otázok: 16 otázok bolo zatvorených, z toho 1 dichotomická, 2 prirad'ovacie, 1 otázka bola polootvorená a 4 otázky otvorené. Prostredníctvom vyučujúcich bol test predložený 330 žiakom zo 7.-9. ročníka základných škôl a zodpovedajúcich ročníkov gymnázií s osemročným štúdiom (konkrétne ZŠ Prokofievova 5, ZŠ Vazovova 4, ZŠ Dubová 1, Gymnázium Pankúchova 6, ZŠ Bieloruská 1, ZŠ Nobelovo nám. 6) a 1.-4. ročníka stredných škôl (Stredná združená škola Račianska 105, Sociálna a pedagogická akadémia, Súkromná veterinárna škola) v Bratislave. Nakolko nás zaujímali trvalé vedomosti (nie krátkodobé), test nebol predkladaný žiakom 6. ročníka (kedy sa táto téma preberá v rámci vyučovacieho procesu) ani žiakom bezprostredne po akcii, ale až s určitým časovým odstupom 1-3 rokov. $Z$ testovanej vzorky žiakov sa cca $70 \%$ akcie zúčastnilo.

Maximálna bodová hodnota, ktorú mohli žiaci dosiahnut' bola 21 bodov. Priemerná bodová hodnota pripadajúca na jedného žiaka bola 12,95 bodu, čo zodpovedá $62 \%$ úspešnosti. Základné školy mali lepšie bodové skóre, v priemere 13,68 bodov, stredné školy mali priemerné bodové skóre iba 11,46 bodov. Žiaci, ktorí sa prenosu ropúch na Železnej studienke zúčastnili dosiahli priemerne 15,28 bodu na žiaka (73\% úspešnost'), čo je dobrý výsledok. Vel'ký vplyv mala naň aj akcia na Železnej studienke. Horšie dopadli žiaci, ktorí sa prenosu ropúch nezúčastnili. Títo dosiahli len 12,78 bodu na žiaka s percentuálnou úspešnostou $61 \%$, čo je o $12 \%$ menej ako pri žiakoch, ktorí sa zúčastnili akcie na Železnej studienke.

Väčšina otázok žiakom nerobila problémy, aj ked' tí žiaci, ktorí sa zúčastnili prenosu ropúch na Železnej studienke, si s nimi vedeli poradit' lepšie (až $90 \%$ otázok zvládli lepšie). $\checkmark$ niektorých odpovediach bol rozdiel len niekolko percent, $v$ iných sa vedomosti líšili omnoho výraznejšie. Relatívne vyrovnané boli odpovede žiakov na "teoretické" otázky vychádzajúce z učiva prírodopisu, či biológie, ako napr. "Do akej triedy živočíchov patria ropuchy?", "Čím sa ropuchy živia?", "Je ropucha studenokrvný alebo teplokrvný živočích?", "Na ktorom obrázku je ropucha a na ktorom skokan?", „Ako sa ropuchy rozmnožujú?" Najväčšie rozdiely boli $v$ "praktických" otázkach. $\vee$ nich mali žiaci, ktorí sa akcie zúčastnili, možnost́ využit nadobudnuté vedomosti. Napríklad na otázku "Akým spôsobom prebieha na jar ochrana ropúch?" mali na výber 3 možnosti odpovedí: a) prenášaním ropúch cez cestné komunikácie, b) umelým odchovom $v$ liahniskách a c) pridávaním potravy do jazierok. Zastúpenie odpovedí žiakov na túto otázku je znázornené v grafe 1 . Nezúčastnení žiaci mali problémy aj s otázkou "Čo znamená pojem jarná migrácia ropúch?" Na výber mali nasledujúce 3 odpovede: a) presun ropúch za potravou, b) presun ropúch kvôli rozmnožovaniu a c) presun zo zimovísk na slnečné stanovištia. Podiel odpovedí žiakov na túto otázku je znázornený $v$ grafe 2 . 
$\square$ zúčastnení $\square$ nezúčastnení

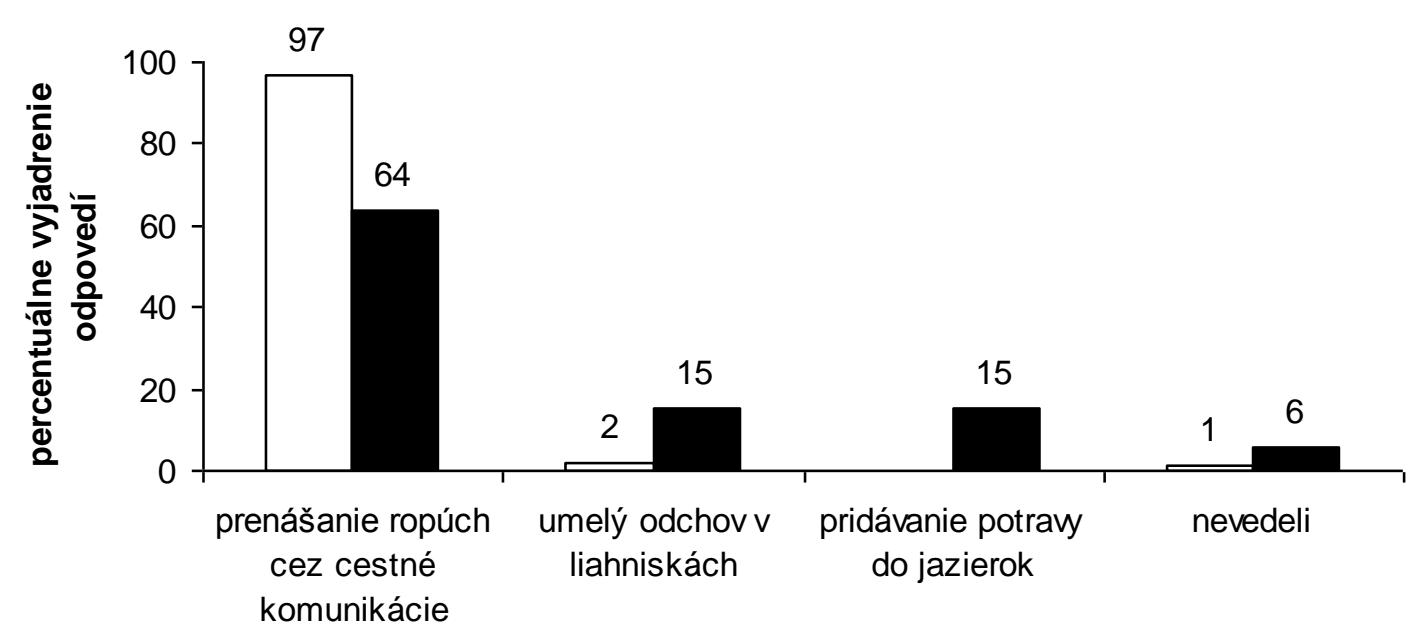

odpovede

Graf 1: Odpovede žiakov na otázku týkajúcu sa spôsobu ochrany ropúch v jarnom období.

$\square$ zúčastnení $\square$ nezúčastnení

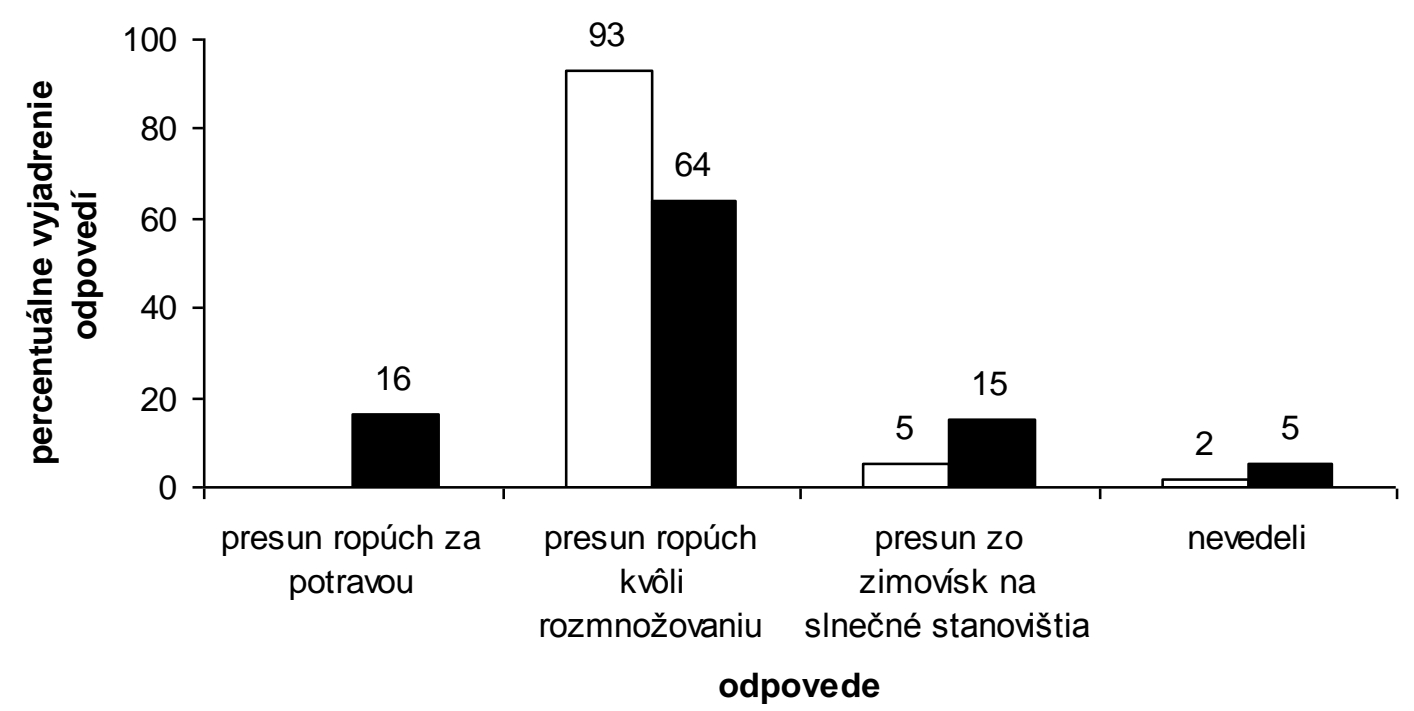

\section{Graf 2: Odpovede žiakov na otázku týkajúcu sa objasnenia významu} pojmu jarná migrácia ropúch.

V mnohých triedach, $v$ ktorých sa aspoň čast' žiakov na prenose zúčastnila, boli výsledky lepšie $v$ porovnaní $s$ triedami, $v$ ktorých sa prenosu na Železnej studienke nezúčastnil ani jeden žiak. Treba si to vysvetlit́ tým, že žiaci, ktorí sa prenosu zúčastnili rozoberali svoje zážitky a dojmy so spolužiakmi, ale aj s učitel'mi, nielen na hodinách prírodopisu, či biológie, ale aj na iných predmetoch. $V$ mnohých triedach, hlavne základných škôl, o tom písali aj slohové práce. Žiaci, ktorí sa prenosu nezúčastnili, sa takto mnohé 
informácie týkajúce sa obojživelníkov dozvedeli od svojich spolužiakov. No všeobecne platí, že nie je nad vlastnú skúsenost́. Preto môžeme predpokladat', že títo žiaci si vedomosti, prijaté od spolužiakov, nezapamätajú až tak dlho, ako tí, ktorí ich sami prežili.

\section{Zhodnotenie názorov učitel'ov na prínos akcie pre žiakov}

S ciel'om zistit pohlad učitel'ov na problematiku aktívneho zapojenia sa žiakov do ochrany prírody, ako aj konkrétneho dopadu akcie "Pomoc ropuchám pri jarných migráciách" na žiakov sme uskutočnili riadené rozhovory s učitel'mi, ktorí sa spolu so žiakmi pravidelne zapájajú do prenosu žiab na Železnej studienke. Celkove sme v roku 2015 uskutočnili riadené rozhovory s 8 vyučujúcimi, pričom sme sa zamerali na takých, ktorí sa spolu zo žiakmi akcie zúčastnili minimálne 5krát. Na základe vlastných skúseností tak môžu objektívnejšie posúdit́ dopad akcie na postoje žiakov, ako napr. učitelia, ktorí sa do akcie zapojili len raz. Konkrétne nás zaujímali odpovede na nasledujúce 4 otázky:

\section{V čom vidíte prínos zapojenia žiakov do prenosu žiab na Železnej studienke?}

Učitelia vidia najväčší prínos v nasledujúcich oblastiach:

- Zážitkové učenie priamo v prírode - žiaci sa učia prirodzenejšie, ked' sú v prostredí, ktoré je pre daný predmet nášho vyučovania typické ( $v$ tomto prípade sú to žaby a ich typické prostredie - les s blízkost́ou vodných plôch). Akcia poskytuje priamy kontakt žiakov s prírodou, nie je iba o žabách. Žiaci sa učia, ako sa majú správat́ v prírode, spoznávajú okolie Bratislavy, chránené územia, okolitú faunu a flóru, získavajú pravdivé informácie o prírode (napr. objasnenie rôznych mýtov a povier súvisiacich s ropuchami).

- Nenásilná forma učenia ekologického správania sa žiakov - v súvislostiach $s$ človekom, ktorý na jednej strane robí život zvyšku prírody tažším (napr. budovaním cestnej siete narúša migračné trasy mnohých živočíchov, vysúšaním mokradí a ich premenou na ornú pôdu alebo stavebné pozemky znižuje počet miest vhodných na rozmnožovanie živočíchov viazaných na tento typ biotopu, atd'.) a na druhej strane vie a musí pomáhat́. Deti si samy vyskúšajú, ako $v$ praxi funguje princíp ochrany prírody, samy sa na nej podiel'ajú. Na vlastné oči vidia a prakticky si vyskúšajú, ako to je. Zistia, že bez pomoci konkrétnych ludí to nefunguje a často treba vynaložit mnoho úsilia aj telesnej práce, aby sme pomohli prírode, čiže bez vlastného pričinenia to nejde. Žiaci získavajú pocit vlastnej dôležitosti a zodpovednosti za ochranu prírody. Navrhujú riešenia a možnosti ako zmiernit́ negatívny vplyv človeka na prírodu.

- Získavanie manuálnych zručností.

\section{Má podl'a Vášho názoru účast' žiakov na tejto akcii nejaký dopad na ich vzt'ah k životnému prostrediu? Aký?}

Všetci učitelia sa zhodli na tom, že akcia má na žiakov velký vplyv. Jednak získajú prirodzenejšie určité vedomosti (napr. že samička je väčšia ako samček), jednak tieto vedomosti majú trvalejší charakter, kedže zapájajú viac zmyslov, ako keby sa dané učivo preberalo $v$ triede (tým, že počúvajú, vidia, ohmatávajú, zažijú na vlastnej koži). Žiaci úplne inak vnímajú, ked'im rozprávame, že niektoré žaby aj zahynú pri ceste do rybníka, ako ked' to vidia na vlastné oči a napr. sami utekajú zachránit́ žabu pred blížiacim sa autom, alebo ich opatrne prenášajú vo vedierkach cez cestu - omnoho viac sa im to dostane "pod kožu" a zafixujú si to. Žiaci si uvedomia, že prírode treba pomôct', lebo tlaky na jej "využitie" sú 
vel'mi silné. Pochopia, že každá rastlina a každý živočích má v prírode svoje nezastupitel'né a nenahraditel'né miesto. Život všetkých rastlín a živočíchov je navzájom prepojený podla zásady všetko so všetkým súvisí. Pozitívnym zistením je aj skutočnost', že akcie zamerané na budovanie kladného vztáahu k prírode vplývajú nielen na žiakov samotných, ale ich prostredníctvom aj na ich rodiny. Učitelia to pozorujú na postupnom zlepšujúcom sa prístupe rodičov, ktorí sa spolu so svojimi det́mi stále častejšie zapájajú do aktivít organizovaných školou a zameraných na spoznávanie a ochranu životného prostredia. Žiaci o svojich zážitkoch rozprávajú nielen rovesníkom, ale aj rodičom a známym, takže pozitívny dopad takýchto podujatí sa ešte umocňuje. Mnohí žiaci po prvý raz v živote vidia na vlastné oči živú žabu (je to smutné, ale $v$ mestskom prostredí, s vysokou dostupnostó informačnokomunikačných technológií, je to realita), takže zo začiatku sú opatrní a "vyzbrojení" rukavicami sa boja priblížit k žabe bližšie ako na 1 meter. Krásne však možno pozorovat' ako sa tento ich postoj dokáže za jedno dopoludnie zmenit́. Pri odchode je to už "moja žabka", ktorú nosia priamo v ruke a neboja sa opýtat', či by si ju nemohli zobrat' so sebou domov...

\section{Vyhl'adávate obdobné aktivity zamerané na praktickú ochranu prírody pre žiakov osobne (na internete, prostredníctvom osobných kontaktov s odborníkmi alebo členmi mimovládnych organizácií) alebo využívate ponuky rôznych aktivít, ktoré prídu na školu.}

Väčšina učitel'ov vzhl'adom na svoju viacročnú prax využíva najmä osobné kontakty na odborníkov, resp. na rôzne mimovládne organizácie, ktoré realizujú aktivity zamerané na zapojenie žiakov do praktickej ochrany prírody. $V$ niektorých prípadoch vedia pomôct́ aj rodičia (ak pracujú $v$ oblasti ochrany prírody, resp. majú na niekoho $z$ tejto oblasti kontakt). Občas využívajú aj ponuky, ktoré prídu na školu. Tieto sú však vo väčšine prípadov spoplatnené, takže je potrebné riešit' spôsob ich financovania (žiakmi, resp. školou).

\section{Aké d’alšie aktivity zamerané na praktickú ochranu prírody ste so žiakmi realizovali?}

Z odpovedí na túto otázku jasne vidiet', že ponuka rôznych akcií pre žiakov je bohatá (aspoň v oblasti Bratislavy) a učitelia pokial' majú záujem a snahu, tak možností na obohatenie vyučovania smerom k praktickým aktivitám je dostatok. $V$ uvedených aktivitách prevládali exkurzie, napr. $v$ rámci projektu Zelená hranica do slovensko-rakúskeho "hraničného" priestoru, do Marcheggu (miesto s najväčším výskytom kolónií bocianov bielych v strednej Európe), do Národného parku Dunajské luhy (Donau-Auen) s informačným centrom v zámku v Orth an der Donau, kde sa deti v rámci vnútorných aj vonkajších expozícií dozvedia množstvo informácií o dunajských lužných lesoch - faune i flóre. Pravidelne spolupracujú s mimovládnou organizáciou Daphne, či firmou Envirokone, ktoré realizujú prírodovedné výučbové programy aj priamo na školách. Spolupracujú aj so Zoologickou záhradou v Bratislave, bratislavským útulkom Slobody zvierat, učia deti separovat' odpad, pravidelne sa starajú o čistotu školského areálu aj okolia školy, zapojili sa do vysádzania stromčekov $v$ lese, ale aj v okolí školy a na sídlisku, pozorovania vtáctva, výroby kŕmidiel pre vtáky a "domčekov" pre hmyz a snažia sa využit každú príležitost', aby mohli žiakov obohatit o nové vedomosti a poznatky.

\section{Záver}

Z uvedených výsledkov je zrejmý pozitívny prínos praktickej ochrany ropúch na lokalite Železná studienka v Bratislave $v$ rámci akcie „Pomoc ropuchám pri jarných migráciách" na vedomosti žiakov, aj ich celkové vnímanie okolitého prostredia. Zatial' čo $v$ prvých rokoch bola prioritným ciel'om tejto akcie druhová ochrana ropuchy bradavičnatej (Bufo bufo), postupne sa omnoho viac dostáva do popredia environmentálna výchova a 
zvyšovanie environmentálneho povedomia detí, mládeže aj dospelých. Žiaci získané vedomosti a skúsenosti využívajú nielen priamo počas vyučovacieho procesu (napr. pri spracovávaní vlastných projektov $v$ rámci projektového vyučovania), alebo častokrát tvoria základ projektov, ktoré prezentujú na projektových sútažiach ako Biologická olympiáda, či Stredoškolská odborná činnost'. Záchrana migrujúcich obojživelníkov predstavuje aktivitu, ktorou pri relatívne nízkom finančnom zatážení môžeme dosiahnut́ vysoký účinok pri ochrane populácií ohrozených druhov živočíchov. Na viacerých miestach na Slovensku sú to práve školy, ktoré si zobrali pod patronát lokalitu vo svojom okolí, na ktorej v minulosti dochádzalo k úhynom obojživelníkov na vozovke a vd’aka aktivitám ich žiakov sa to významne zmenilo.

Príspevok vznikol za podpory grantu KEGA č. 070UK-4/2015.

\section{Literatúra}

- Danková, A. (2008). Zistovanie vplyvu aktivít zameraných na záchranu migrujúcich obojživelníkov na vedomostnú úroveň žiakov. Diplomová práca.. Bratislava: Katedra krajinnej ekológie, Prírodovedecká fakulta, Univerzita Komenského v Bratislave.

- Chrenščová, V. (2012). Exkurzie v environmentálnej výchove a ich využívanie na slovenských základných školách. Envigogika, 7(1), Retrieved from http://www.envigogika.cuni.cz/index.php/Envigogika/article/view/70 http://dx.doi.org/10.14712/18023061.70

- Kminiak, M. (1997). Environmentálna výchova, učebné materiály, teoretické základy, školská výchova a prax. VŠ skriptá. Bratislava: Prírodovedecká fakulta, Univerzita Komenského.

- Kminiak, M., Kováčik, J., (1975). Jarná aktivita ropuchy obyčajnej [Bufo bufo (L. 1758)] v povodí potoka Vydrice (pri Bratislave). Biológia, 30(8),

- Kováčik, J. (1974). Sezónna dynamika ropuchy obyčajnej, Bufo bufo (L. 1758) na Železnej studienke (pri Bratislave). Diplomová práca. Bratislava: Katedra systematickej zoológie a ekológie, Prírodovedecká fakulta UK v Bratislave..

- Lehotská, B., \& Lehotský, R. (2000). Žaby - naše druhy, ich ohrozenie a možnosti ochrany. 15 rokov akcie "Pomoc ropuchám pri jarných migráciách" na Železnej studienke $v$ Bratislave. : lovenský zväz ochrancov prírody a krajiny.

- Nevřelová, M. (2008). Environmentálna výučba vo výchovno-vzdelávacom procese. Bratislava: CICERO s.r.o..

- Novanská, V. (2014). Environmentálna výchova ako prierezová téma v edukačnom procese na slovenských základných školách. Biológia, ekológia, chémia, 18(1), 28.

- Vyhláška MŽP SR č. 158/2014 Z. z., ktorou sa mení a dopíňa vyhláška MŽP SR č. 24/2003 Z. z., ktorou sa vykonáva zákon č. 543/2002 Z. z. o ochrane prírody a krajiny $\vee$ znení neskorších predpisov. 


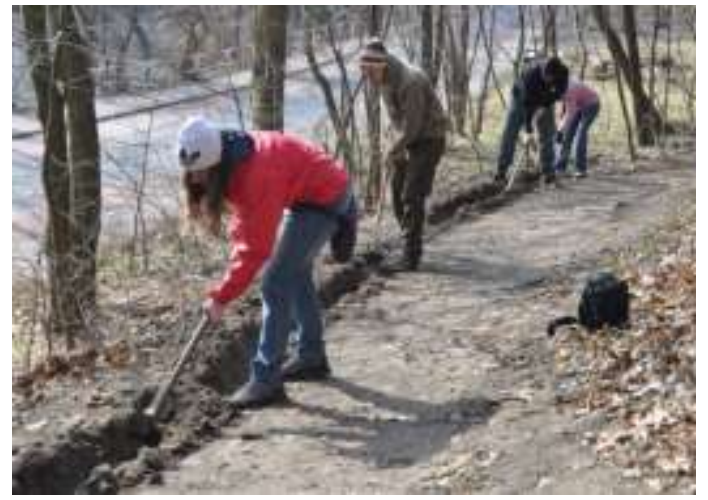

Obr. 1: Kopanie jarčeka, do ktorého sa bude umiestňovat' fóliová zábrana. Foto: $\mathbf{R}$.

Lehotský, 2013

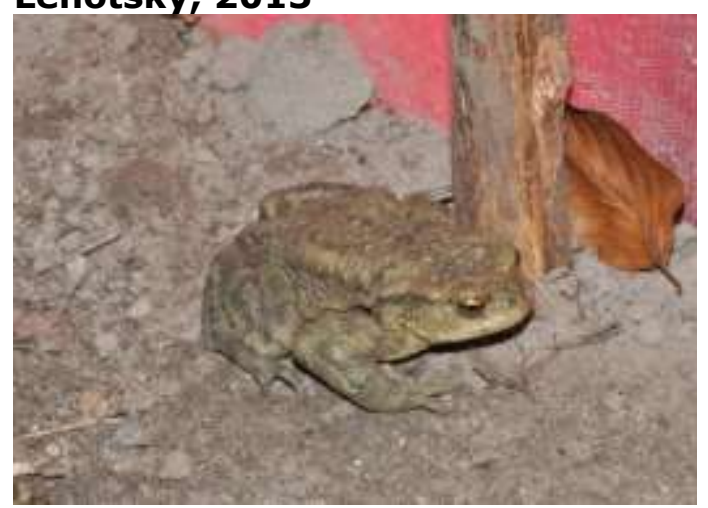

Obr. 3: Samec ropuchy bradavičnatej (Bufo bufo) pri zábrane. Foto: B. Lehotská, 2014

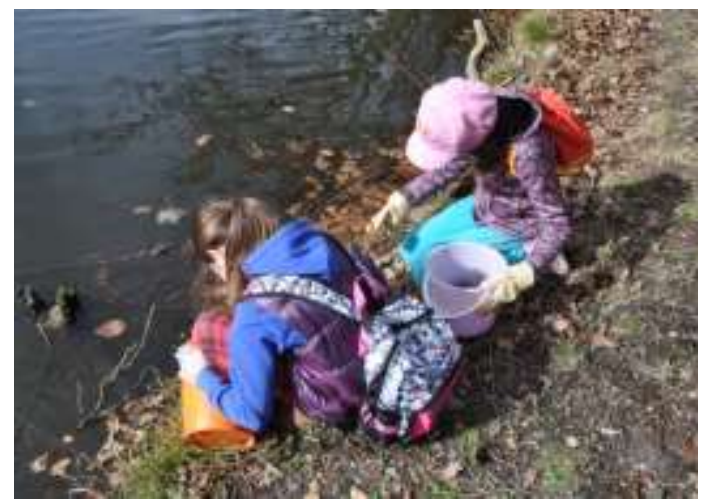

Obr. 5: Vypúšt́anie prenesených ropúch do rybníka. Foto: B. Lehotská, 2014

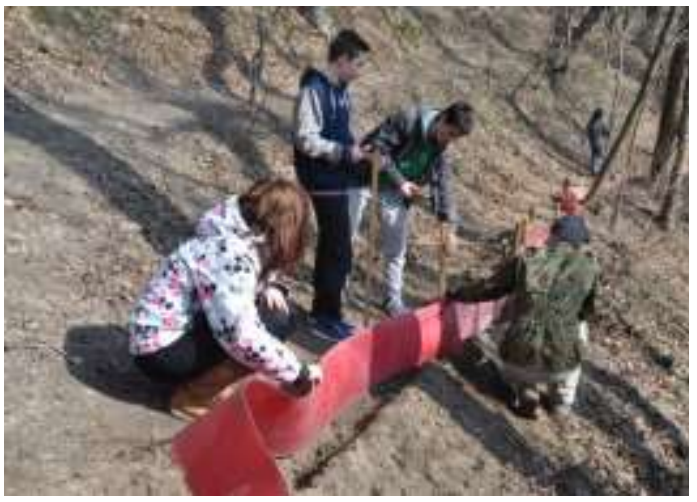

Obr. 2: Pripevňovanie fólie drevenými kolíkmi. Foto: $R$. Lehotský, 2013

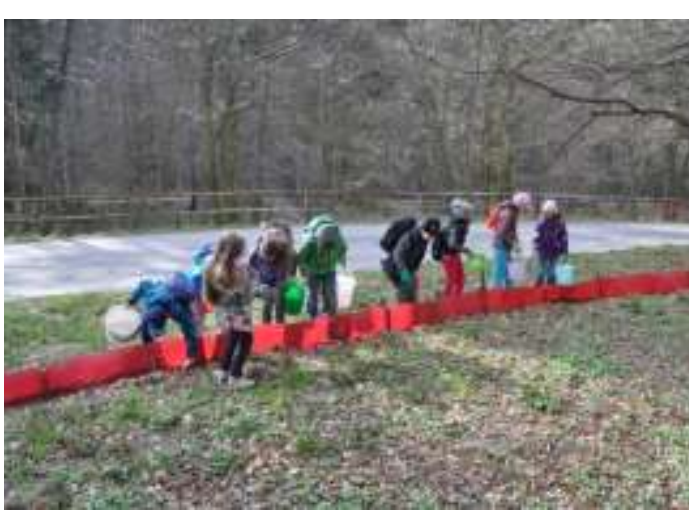

Obr. 4: Zber ropúch čakajúcich pri zábranách na prenos cez cestu. Foto: B. Lehotská, 2014

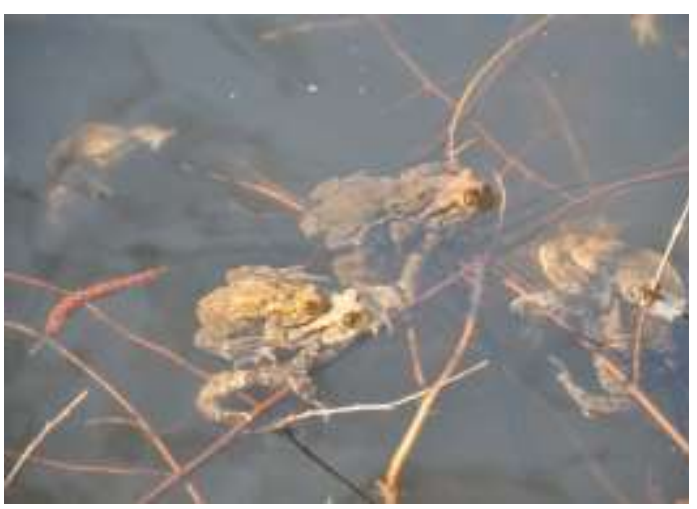

Obr. 6: Páriky ropuchy bradavičnatej s nakladenými vajíčkami $v$ tvare dlhých retiazok. Foto: B. Lehotská, 2011 